\title{
Bacteroides paurosaccharolyticus sp. nov., isolated from a methanogenic reactor treating waste from cattle farms
}

\author{
Correspondence \\ Atsuko Ueki \\ uatsuko@tds1.tr.yamagata-u.ac.jp
}

\author{
Atsuko Ueki, ${ }^{1}$ Kunihiro Abe, ${ }^{1}$ Yoshimi Ohtaki, ${ }^{1}$ Nobuo Kaku, ${ }^{1}$ \\ Kazuya Watanabe ${ }^{2}$ and Katsuji Ueki ${ }^{1}$ \\ ${ }^{1}$ Faculty of Agriculture, Yamagata University, Wakaba-machi 1-23, Tsuruoka 997-8555, Japan
${ }^{2}$ Exploratory Research for Advanced Technology (ERATO), JST, University of Tokyo, 7-3-1 Hongo,
Bunkyo-ku, Tokyo 113-8656, Japan
}

Bacteroides species are strictly anaerobic, Gram-stainingnegative, non-spore-forming rods and are major members of the bacterial flora in the human colon and in human faeces (Holdeman et al., 1984; Paster et al., 1994). Although bacterial clones belonging to the genus Bacteroides have often been detected as dominant members of the bacterial flora in methanogenic reactors (Chouari et al., 2005; Godon et al., 1997; Levén et al., 2007), only a few strains affiliated to Bacteroides have been isolated from this or similar habitats (Nishiyama et al., 2009b; Ueki et al., 2008; Whitehead et al., 2005). In this study, we describe a novel species in the genus Bacteroides based on the phylogenetic, physiological and chemotaxonomic characteristics of strain $\mathrm{WK} 042^{\mathrm{T}}$ isolated from a methanogenic reactor.

Strain $\mathrm{WK} 042^{\mathrm{T}}$ was isolated from a sample of rice-straw residue obtained from a methanogenic reactor treating

Abbreviation: CFA, cellular fatty acid.

The GenBank/EMBL/DDBJ accession number for the $16 \mathrm{~S}$ rRNA gene sequence of strain $\mathrm{WKO}^{\top} 2^{\top}$ is $\mathrm{AB} 298727$. waste collected from cattle farms (up to 1000 cattle in total) in Betsukai-machi, Hokkaido, Japan. The reactor was a vertically cylindrical type $\left(1500 \mathrm{~m}^{3}\right)$ operated at $35^{\circ} \mathrm{C}$. Rice straw used as matting at the cattle farms, containing cattle faeces and urine, was thrown into the reactor and treated as waste (Nishiyama et al., 2009a, b; Ueki et al., 2008).

Strain $\mathrm{WK} 042^{\mathrm{T}}$ was isolated by the anaerobic roll-tube method for enumeration of anaerobic fermentative bacteria (Hungate, 1966; Holdeman et al., 1977). The ricestraw samples obtained from the reactor were washed several times with sterile anoxic diluent and homogenized in a Waring blender (10 000 r.p.m. for $10 \mathrm{~min}$ ) under a $\mathrm{N}_{2}$ atmosphere. The homogenized samples were successively diluted (10-fold) anaerobically and used as inocula to the anaerobic roll-tube agar (PY4S medium) for isolation of anaerobic bacteria (Akasaka et al., 2003a). Colonies that formed on the agar were picked at random after incubation for 2 weeks at $30{ }^{\circ} \mathrm{C}$ and about 50 isolates were obtained from a sample. Strain $\mathrm{WK} 042^{\mathrm{T}}$ was selected as a 
representative of four strains that showed similar phenotypic properties and similar denaturing gradient gel electrophoresis profiles based on the V3 region of the $16 \mathrm{~S}$ rRNA gene sequence (Ueki et al., 2008). Strain WK042 ${ }^{\mathrm{T}}$ was picked from a roll-tube inoculated with a sample diluted $10^{-4}$.

Strain WK0 $042^{\mathrm{T}}$ was cultivated anaerobically at $30{ }^{\circ} \mathrm{C}$ unless stated otherwise by using peptone/yeast extract (PY) as the basal medium with oxygen-free mixed gas $\left(\mathrm{N}_{2} / \mathrm{CO}_{2}, 95: 5\right)$ as the headspace, as described by Ueki et al. (2006a). PY medium supplemented with (per litre) $0.25 \mathrm{~g}$ each of glucose, cellobiose, maltose and soluble starch as well as $15 \mathrm{~g}$ agar (Difco) was designated PY4S agar and used for maintenance of the strain on agar slants. PY broth supplemented with haemin (at a final concentration of $5 \mathrm{mg} \mathrm{l}^{-1}$ ) (Holdeman et al., 1977) (PYH) and a B-vitamin mixture $\left(10 \mathrm{ml} \mathrm{l}^{-1}\right)$ (PYHV) (Ueki et al., 2006b, 2008) as well as $10 \mathrm{~g}$ glucose $\mathrm{l}^{-1}$ (PYHVG) was used for cultivation of strain $\mathrm{WK} 042^{\mathrm{T}}$ for various physiological tests and chemotaxonomic analyses unless stated otherwise. When cyanocobalamin (cobalamin or vitamin $\mathrm{B}_{12}$ ) was used as a sole vitamin added to the medium, it was used at the same concentration as that in the B-vitamin mixture. The $\mathrm{pH}$ of all media was adjusted to 7.0-7.3 except for determination of the $\mathrm{pH}$ range for growth of strain WK042 ${ }^{\mathrm{T}}$. Bacteroides massiliensis JCM $13223^{\mathrm{T}}$ and Bacteroides vulgatus JCM $5826^{\mathrm{T}}$ were cultivated in the same media and under the same conditions as strain $\mathrm{WK} 042^{\mathrm{T}}$ and their phenotypic characteristics were determined by using the same methods described below.

Growth of strain WK042 ${ }^{\mathrm{T}}$ under aerobic conditions was examined as described previously (Ueki et al., 2006a). Spore formation was assessed by observing cells after Gram staining, and production of thermotolerant cells was examined by cultivating heat-treated $\left(80{ }^{\circ} \mathrm{C}\right.$ for $\left.10 \mathrm{~min}\right)$ cells in PYHVG broth. The motility of cells (from both slant and broth cultures) was examined via phase-contrast microscopy. Oxidase and nitrate-reducing activities were determined according to the methods described by Akasaka et al. (2003b). Catalase activity was examined by using cells cultivated in liquid medium and collected by centrifugation. A small amount of $\mathrm{H}_{2} \mathrm{O}_{2}$ solution $(3 \%, \mathrm{v} / \mathrm{v})$ was mixed with the cell pellet (Wilkins et al., 1978). The optimum growth conditions were tested at $5-45{ }^{\circ} \mathrm{C}$ (at $5{ }^{\circ} \mathrm{C}$ intervals with an exception at $37{ }^{\circ} \mathrm{C}$ ), in the presence of $0,0.5,1,2$ and $3 \%(\mathrm{w} / \mathrm{v}) \mathrm{NaCl}$ in PHHVG broth and at $\mathrm{pH} 4.1,4.8,5.7,6.8,7.7,8.2,9.0$ and 10.3 (pH verified after autoclaving). Bicine (Good's buffer; Dotite) $(20 \mathrm{mM})$ was used to adjust the medium to $\mathrm{pH}$ values greater than 8.0 in modified PYHVG broth (Ueki et al., 2008). Growth in liquid medium was monitored by changes in $\mathrm{OD}_{660}$. Utilization of carbon sources was tested in PYHV broth, each substrate being added at $10 \mathrm{~g} \mathrm{l}^{-1}$ (for sugars and sugar alcohols) or $30 \mathrm{mM}$ (for organic acids). Utilization of each substrate was determined from growth measurements $\left(\mathrm{OD}_{660}\right)$ as well as by determining fermentation products in the medium after cultivation. Fermentation products were analysed by GC or HPLC as described previously (Ueki et al., 1986; Akasaka et al., 2003a). Bile sensitivity was determined in PYHVG broth supplemented with $0.1-2 \%(\mathrm{w} / \mathrm{v})$ oxgall (Difco). Production of urease, $\mathrm{H}_{2} \mathrm{~S}$ and indole as well as hydrolysis of aesculin and gelatin were tested according to the methods described by Holdeman et al. (1977).

Cells of strain WK042 ${ }^{\mathrm{T}}$ were Gram-staining-negative, nonmotile rods. The strain grew as very thin, translucent colonies with a smooth surface on PY4S agar. Strain $\mathrm{WK} 042^{\mathrm{T}}$ did not grow in air, on either PY4S or nutrient agar. Spore formation was not observed and thermotolerant cells were not produced.

Strain WK042 ${ }^{\mathrm{T}}$ grew very slowly in PYG broth (without haemin and the B-vitamin mixture) at a growth rate $(\mu)$ of $0.075 \mathrm{~h}^{-1}$, but the addition of haemin (PYHG) stimulated growth dramatically $\left(\mu=0.208 \mathrm{~h}^{-1}\right)$. Addition of the vitamin mixture or cobalamin to the medium further enhanced growth $\left(\mu=0.244 \mathrm{~h}^{-1}\right)$. The vitamin mixture and cobalamin each showed similar effects on growth and thus cobalamin appeared to stimulate growth of the strain. Addition of the vitamin mixture or cobalamin alone (without haemin) did not enhance growth. Further supplementation of the medium with vitamin $\mathrm{K}$ did not appear to affect the growth rate. Thus, physiological characteristics of the strain were usually determined in the presence of haemin and the vitamin mixture (PYHV broth). When cells rapidly grown in PYHVG broth to the stationary phase were used as inocula to the same fresh medium, growth was usually delayed significantly, suggesting that most of the cells had lost the ability to grow. Thus, the strain was usually maintained on PY4S agar slants (without haemin) with rather short transfer intervals for safe preservation.

Catalase activity was not detected in cells grown in PY4S agar slants or in liquid media (PYG, PYHG or PYHVG). Strain WK042 $2^{\mathrm{T}}$ utilized only a restricted range of substrates to support rapid growth, namely arabinose, xylose, glucose, mannose and aesculin. The final $\mathrm{pH}$ after growth was 4.95.1. Although maltose, dextrin, glycogen, starch and pectin were also utilized by the strain, growth on these substrates was much delayed compared with that on the substrates mentioned above. Rhamnose and pyruvate were utilized weakly. Substrates tested but not used by strain $\mathrm{WK} 042^{\mathrm{T}}$ are listed in the species description. The strain produced acetate $\left(2.8 \mathrm{mmol} \mathrm{l}^{-1}\right)$, propionate $\left(4.6 \mathrm{mmol} \mathrm{l}^{-1}\right)$ and succinate $\left(6.8 \mathrm{mmol} \mathrm{l}^{-1}\right)$ from glucose in PYHV medium. Almost the same amounts of products were formed from arabinose and xylose. When grown on pyruvate, propionate was the dominant product $\left(8.2 \mathrm{mmol} \mathrm{l}^{-1}\right)$ together with acetate $\left(4.2 \mathrm{mmol} \mathrm{l}^{-1}\right)$, while succinate was detected as only a minor product $\left(1.0 \mathrm{mmol} \mathrm{l}^{-1}\right)$. Strain $\mathrm{WK} 042^{\mathrm{T}}$ grew at pH 5.7-9.0; it was slightly alkaliphilic, with optimum growth at about $\mathrm{pH} 7.7(\mu=0.233,0.271$ and $0.132 \mathrm{~h}^{-1}$ at $\mathrm{pH} 6.8,7.7$ and 8.2 , respectively). The temperature range for growth was $10-40{ }^{\circ} \mathrm{C}$, the optimum 
being at $35{ }^{\circ} \mathrm{C}\left(\mu=0.239,0.348\right.$ and $0.302 \mathrm{~h}^{-1}$ at 30,35 and $37{ }^{\circ} \mathrm{C}$, respectively). The strain did not grow at 5 or $45{ }^{\circ} \mathrm{C}$. The $\mathrm{NaCl}$ concentration range for growth was $0-2 \%(\mathrm{w} / \mathrm{v}$, in PYHVG medium) and optimum growth occurred in the absence of added $\mathrm{NaCl}$. The strain was sensitive to bile; oxgall inhibited growth completely, even at $0.1 \%(\mathrm{w} / \mathrm{v})$. Other physiological characteristics are detailed in the species description.

The almost-complete 16S rRNA gene sequence of strain WK042 ${ }^{\mathrm{T}}$ was PCR-amplified by using the primer pair $8 \mathrm{f}$ and 1546r and a DNA sample was extracted from cells as described previously (Akasaka et al., 2003b). The PCRamplified 16S rRNA gene was sequenced by using an ABI Prism BigDye terminator cycle sequencing ready reaction kit and an ABI Prism 3730 automatic DNA sequencer (Applied Biosystems). Multiple alignments of the amplified sequence (1476 bp) with reference sequences in GenBank were performed with the BLAST program (Altschul et al., 1997). A phylogenetic tree was constructed with the neighbour-joining method (Saitou \& Nei, 1987) by using the CLUSTAL W program (Thompson et al., 1994) and with the maximum-likelihood program (DNAML) of the PHYLIP 3.66 package (Felsenstein, 2006). All gaps and unidentified base positions in the alignments were excluded before sequence assembly.

Phylogenetic analysis based on 16S rRNA gene sequences placed strain WK042 $2^{\mathrm{T}}$ in the phylum Bacteroidetes (Garrity \& Holt, 2001). Strain WK042 ${ }^{\mathrm{T}}$ had at least two different 16S rRNA gene sequences, with $\mathrm{C}$ or $\mathrm{T}$ at position 183 (Escherichia coli numbering). Strain WK042 ${ }^{\mathrm{T}}$ was related most closely to B. massiliensis $\mathrm{B} 84634^{\mathrm{T}}$ (Fenner et al., 2005) isolated from blood culture of a healthy baby $(92.2 \% 16 \mathrm{~S}$ rRNA gene sequence similarity), B. vulgatus ATCC $8482^{\mathrm{T}}$ (Holdeman et al., 1984) isolated from human faeces $(92.1 \%)$ and Bacteroides dorei JCM $13471^{\mathrm{T}}$ (Bakir et al., 2006), also isolated from human faeces (91.3\%). Levels of similarity were calculated by using the sequence giving the highest value, i.e. with $\mathrm{T}$ at position 183 for comparison with B. massiliensis $\mathrm{B} 84634^{\mathrm{T}}$ and with $\mathrm{C}$ for comparison with B. vulgatus ATCC $8482^{\mathrm{T}}$. In contrast to the three other strains, in $B$. dorei JCM $13471^{\mathrm{T}}$ the base at this position was G. Strain $\mathrm{WK} 042^{\mathrm{T}}$ formed a distinct branch in the phylogenetic tree constructed by using the neighbourjoining method (Fig. 1). The tree topology evaluated by the maximum-likelihood method was essentially the same (not shown).

For cellular fatty acid (CFA) analysis, strain $\mathrm{WK} 042^{\mathrm{T}}, B$. massiliensis JCM $13223^{\mathrm{T}}$ and B. vulgatus $\mathrm{JCM} 5826^{\mathrm{T}}$ were cultivated in PYHVG broth for $72 \mathrm{~h}$ at $30{ }^{\circ} \mathrm{C}$. CFAs were converted to methyl esters by saponification and methylation by using the cell biomass according to the method of Miller (1982). CFAs were extracted from the reaction mixtures, and the compositions were analysed by GC (Hewlett Packard HP6890 or Hitachi G-3000), the chromatograph being equipped with an HP Ultra 2 column. Each peak was identified from its equivalent chain-length (Miyagawa et al., 1979) according to the protocol of TechnoSuruga (Shimidu, Japan) (Moore et al., 1994). The major CFAs of strain $\mathrm{WK} 042^{\mathrm{T}}$ were anteiso$\mathrm{C}_{15: 0}(24.5 \%)$, iso- $\mathrm{C}_{17: 0} 3-\mathrm{OH}(15.5 \%), \mathrm{C}_{15: 0}(12.9 \%)$, $\mathrm{C}_{16: 0}(7.2 \%)$, anteiso- $\mathrm{C}_{13: 0}(6.9 \%)$, iso- $\mathrm{C}_{15: 0}(6.7 \%)$ and iso- $\mathrm{C}_{13: 0}(6.6 \%)$. The overall CFA profiles of strain

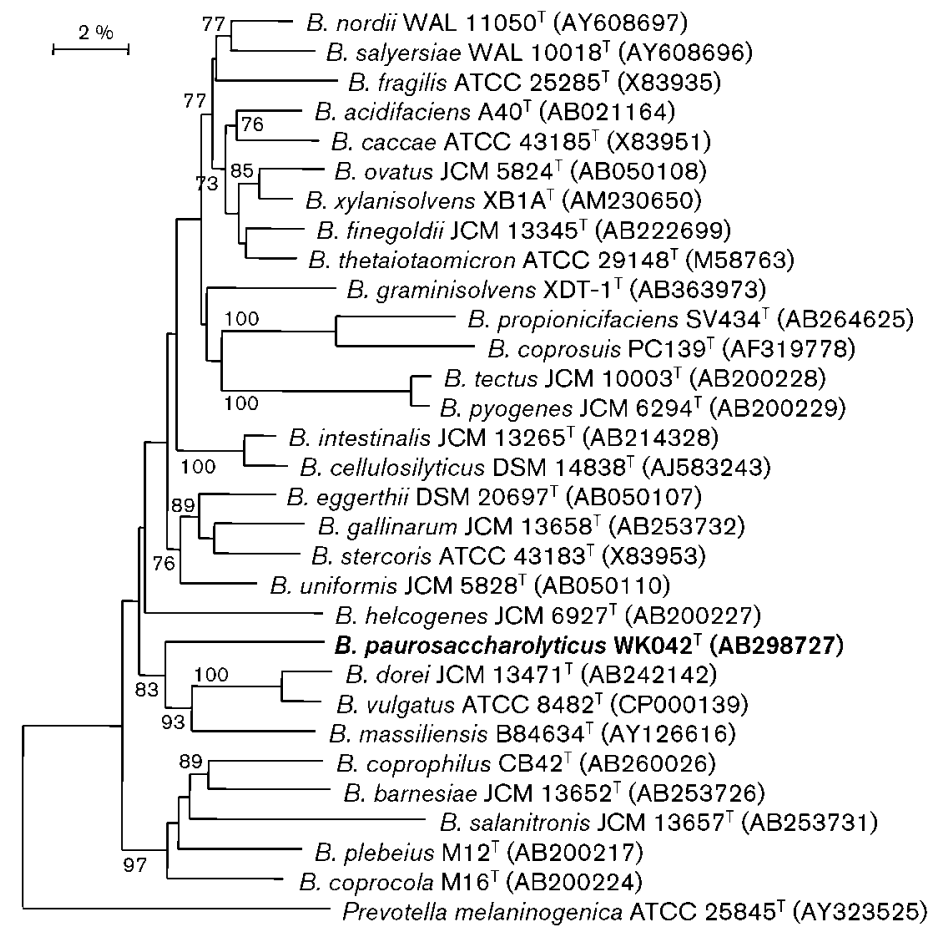

Fig. 1. Neighbour-joining tree showing the phylogenetic relationship between strain WKO42 ${ }^{\top}$ and the type strains of recognized Bacteroides species based on 16S rRNA gene sequences. Bootstrap values (expressed as percentages of 1000 replications) above $70 \%$ are shown at branch nodes. The sequence of Prevotella melaninogenica ATCC $25845^{\top}$ was used as the outgroup. The tree topology evaluated by using the maximum-likelihood method was almost the same as that obtained with the neighbourjoining method. Bar, $2 \%$ estimated difference in nucleotide sequence position. 
WK042 ${ }^{\mathrm{T}}$ and the two reference strains were rather similar (Table 1), sharing common features with all Bacteroides species in having anteiso- $\mathrm{C}_{15: 0}$, iso- $\mathrm{C}_{17: 0} 3-\mathrm{OH}$ and $\mathrm{C}_{15: 0}$ as major components (Miyagawa et al., 1979; Moore et al., 1994). However, the profile of strain $\mathrm{WK} 042^{\mathrm{T}}$ differed from those of related species by the respective proportions of some CFAs, such as $\mathrm{C}_{15: 0}$ and iso- $\mathrm{C}_{15: 0}$.

Genomic DNA of the three strains was extracted according to the method described by Akasaka et al. (2003b) and digested with P1 nuclease by using a Yamasa GC kit (Yamasa Shoyu). DNA G $+\mathrm{C}$ contents were measured by HPLC (L-7400; Hitachi) equipped with a $\mu$ Bondapak C18 column $(3.9 \times 300 \mathrm{~mm}$; Waters $)$. The genomic DNA G $+\mathrm{C}$ content of strain $\mathrm{WK} 042^{\mathrm{T}}$ was $41.0 \mathrm{~mol} \%$. Those of $B$. massiliensis JCM $13223^{\mathrm{T}}$ and B. vulgatus JCM $5826^{\mathrm{T}}$ determined in this study were 45.8 and $44.3 \mathrm{~mol} \%$, respectively. Isoprenoid quinones were extracted as described by Komagata \& Suzuki (1987) and analysed by using a mass spectrometer (JMS-SX102A; JEOL). Menaquinone 11 (MK-11) was the major respiratory quinone of strain $\mathrm{WK} 042^{\mathrm{T}}$.

Strain $\mathrm{WK} 042^{\mathrm{T}}$ shared common characteristics (e.g. cell morphology, haemin requirement, products from glucose and respiratory quinone composition) with recognized

Table 1. Cellular fatty acid compositions of strain $W K 042^{\top}$ and the type strains of related Bacteroides species

Strains: 1 , WK042 $2^{\mathrm{T}} ; 2$, B. massiliensis JCM $13223^{\mathrm{T}} ; 3$, B. vulgatus JCM $5826^{\mathrm{T}}$. Data were obtained in this study. Values are percentages of total fatty acids; fatty acids amounting to $<0.5 \%$ of the total in all three strains are not shown. $\operatorname{tr}$, Trace $(<0.5 \%)$; , not detected.

\begin{tabular}{|c|c|c|c|}
\hline Fatty acid & 1 & 2 & 3 \\
\hline \multicolumn{4}{|l|}{ Saturated straight chain } \\
\hline $\mathrm{C}_{13: 0}$ & 1.0 & - & $\operatorname{tr}$ \\
\hline $\mathrm{C}_{14: 0}$ & 2.0 & 1.3 & 0.7 \\
\hline $\mathrm{C}_{15: 0}$ & 12.9 & 2.9 & 14.7 \\
\hline $\mathrm{C}_{16: 0}$ & 7.2 & 5.4 & 1.5 \\
\hline $\mathrm{C}_{17: 0}$ & 1.3 & - & - \\
\hline $\mathrm{C}_{18: 0}$ & - & 1.6 & - \\
\hline \multicolumn{4}{|l|}{ Saturated branched chain } \\
\hline iso- $\mathrm{C}_{13: 0}$ & 6.6 & 1.6 & 1.3 \\
\hline anteiso- $\mathrm{C}_{13: 0}$ & 6.9 & 4.1 & 2.8 \\
\hline iso- $\mathrm{C}_{14: 0}$ & 1.0 & 1.5 & 2.4 \\
\hline iso- $\mathrm{C}_{15: 0}$ & 6.7 & 14.0 & 7.7 \\
\hline anteiso- $\mathrm{C}_{15: 0}$ & 24.5 & 34.1 & 30.3 \\
\hline iso- $\mathrm{C}_{16: 0}$ & $\operatorname{tr}$ & 1.7 & 0.6 \\
\hline iso- $\mathrm{C}_{17: 0}$ & 1.4 & 4.1 & $\operatorname{tr}$ \\
\hline anteiso- $\mathrm{C}_{17: 0}$ & 1.4 & 2.6 & $\operatorname{tr}$ \\
\hline \multicolumn{4}{|l|}{ Hydroxy } \\
\hline $\mathrm{C}_{15: 0} 3-\mathrm{OH}$ & $\operatorname{tr}$ & 0.9 & 3.1 \\
\hline $\mathrm{C}_{16: 0} 3-\mathrm{OH}$ & 3.0 & 3.1 & 2.9 \\
\hline iso- $\mathrm{C}_{17: 0} 3-\mathrm{OH}$ & 15.5 & 16.5 & 21.8 \\
\hline anteiso- $\mathrm{C}_{17: 0} 3-\mathrm{OH}$ & 2.0 & - & 2.4 \\
\hline $\mathrm{C}_{17: 0} 3-\mathrm{OH}$ & 1.5 & - & 1.8 \\
\hline
\end{tabular}

Bacteroides species (Holdeman et al., 1977, 1984; Shah \& Collins, 1980), supporting its assignment to the genus Bacteroides based on 16S rRNA gene sequence analysis. However, strain $\mathrm{WK} 042^{\mathrm{T}}$ displayed a number of characteristics that differentiated it from closely related species $(B$. massiliensis and B. vulgatus) (Table 2). The two closest relatives of strain $\mathrm{WK} 042^{\mathrm{T}}$ were derived from human faeces. Their growth was stimulated strongly in the presence of oxgall $(2 \%)$, whereas strain $\mathrm{WK} 042^{\mathrm{T}}$ did not grow even in the presence of only a small amount $(0.1 \%)$ of oxgall. The substrate utilization range of strain $\mathrm{WK} 042^{\mathrm{T}}$ was relatively restricted, and the strain did not use the variety of saccharides utilized by $B$. massiliensis and $B$. vulgatus. The optimum temperature for growth $\left(35^{\circ} \mathrm{C}\right)$ and the slightly alkaliphilic character of strain $\mathrm{WK} 042^{\mathrm{T}}$ were in contrast to its closest relatives. The genomic DNA $\mathrm{G}+\mathrm{C}$ content of strain WK042 ${ }^{\mathrm{T}}$ was slightly lower than those of the type strains of B. massiliensis and B. vulgatus.

Almost all substrates preferably utilized by strain $\mathrm{WK} 042^{\mathrm{T}}$ (arabinose, xylose, glucose and mannose) are major components of hemicellulose and cellulose in plant biomass (Collins et al., 2005; Hopkins et al., 2003). Thus, it seems likely that the bacterium lives mainly on monomers derived from the degradation of plant biomass by other hemicellulose or cellulose decomposers. This is in agreement with the source of isolation (rice-straw residue in a methanogenic reactor) of strain $\mathrm{WK}_{0} 42^{\mathrm{T}}$. The significance of the ability of members of the BacteroidesPrevotella group to decompose hemicellulose or xylan has been discussed previously (Chassard et al., 2008; Hespell \&

Table 2. Characteristics that differentiate strain $\mathrm{WK} 042^{\top}$ from type strains of related Bacteroides species

Strains: 1 , WK042 ${ }^{\mathrm{T}} ; 2$, B. massiliensis JCM $13223^{\mathrm{T}} ; 3$, B. vulgatus JCM $5826^{\mathrm{T}}$. + , Positive; - , negative; s, stimulatory; w, weakly positive. All data are from this study. The DNA G $+\mathrm{C}$ contents reported in the original species descriptions of B. massiliensis (Fenner et al., 2005) and B. vulgatus (Holdeman et al., 1984) are shown in parentheses. All other data are in agreement with the original descriptions.

\begin{tabular}{|lccc|}
\hline Characteristic & $\mathbf{1}$ & $\mathbf{2}$ & $\mathbf{3}$ \\
\hline $\begin{array}{l}\text { Genomic DNA G+C content } \\
(\text { mol\%) }\end{array}$ & 41.0 & $45.8(49)$ & $44.3(40-42)$ \\
Optimum growth temperature & 35 & 37 & 37 \\
$\quad\left({ }^{\circ} \mathrm{C}\right)$ & & & \\
Growth in bile & - & $\mathrm{S}$ & $\mathrm{S}$ \\
Acid production from: & & & \\
$\quad$ Arabinose & + & - & + \\
Xylose & + & - & + \\
Fructose & - & + & + \\
Lactose & - & + & + \\
Melibiose & - & + & $\mathrm{W}$ \\
Sucrose & - & + & + \\
Raffinose & - & + & + \\
\end{tabular}


Whitehead, 1990; Nishiyama et al., 2009b; Ueki et al., 2006b, 2007).

Based on the phylogenetic, physiological and chemotaxonomic data presented, strain $\mathrm{WK} 042^{\mathrm{T}}$ is considered to represent a novel species of the genus Bacteroides, for which the name Bacteroides paurosaccharolyticus sp. nov. is proposed.

\section{Description of Bacteroides paurosaccharolyticus sp. nov.}

Bacteroides paurosaccharolyticus (pau.ro.sac.cha.ro.ly'ti.cus. Gr. adj. pauros little or a few; Gr. n. sakchâr sugar; Gr. adj. lutikos dissolving; N.L. masc. adj. paurosaccharolyticus dissolving a few kinds of sugars).

Cells are Gram-staining-negative, non-motile, non-sporeforming rods, $0.7-0.8 \mu \mathrm{m}$ wide and $1.3-5.0 \mu \mathrm{m}$ long. Strictly anaerobic. Colonies are thin and translucent with a smooth surface. Haemin stimulates growth considerably, and cobalamin (vitamin $\mathrm{B}_{12}$ ) enhances growth slightly. Utilizes arabinose, xylose, glucose, mannose and aesculin. Maltose, dextrin, glycogen, starch and pectin are also used, although growth is quite slow. Utilizes rhamnose and pyruvate weakly. Produces acetate, propionate and succinate from saccharides in the presence of haemin and cobalamin. Does not utilize ribose, fructose, galactose, sorbose, cellobiose, lactose, melibiose, sucrose, trehalose, melezitose, raffinose, CMcellulose, cellulose powder, xylan, inulin, amygdalin, salicin, glycerol, dulcitol, inositol, mannitol, sorbitol, ethanol, fumarate, lactate, malate or succinate. Slightly alkaliphilic; optimum growth at $\mathrm{pH}$ 7.7. The temperature range for growth is $10-40{ }^{\circ} \mathrm{C}$ (optimum $35{ }^{\circ} \mathrm{C}$ ). Grows in the presence of $0-2 \%(\mathrm{w} / \mathrm{v}) \mathrm{NaCl}$, with optimum growth in the absence of $\mathrm{NaCl}$. Negative for catalase, oxidase, nitrate reduction and urease activity. Does not produce indole or hydrogen sulfide. Aesculin is hydrolysed but gelatin is not. Sensitive to bile. The major CFAs are anteiso- $\mathrm{C}_{15: 0}$, iso- $\mathrm{C}_{17: 0} 3-\mathrm{OH}$ and $\mathrm{C}_{15: 0}$. The major respiratory quinone is menaquinone 11 (MK-11). The genomic DNA $\mathrm{G}+\mathrm{C}$ content of the type strain is $41.0 \mathrm{~mol} \%$.

The type strain, WK042 ${ }^{\mathrm{T}}\left(=\mathrm{JCM} 15092^{\mathrm{T}}=\mathrm{DSM} 21004^{\mathrm{T}}\right)$, was isolated from a sample of rice-straw residue in a methanogenic reactor treating waste from cattle farms in Japan.

\section{Acknowledgements}

This work was partly supported by a Grant-in-Aid from the Institute for Fermentation, Osaka, and by the Project for Development of Technology for Analysing and Controlling the Mechanism of Biodegrading and Processing supported by the New Energy and Industrial Technology Development of Organization (NEDO). We are grateful to Dr T. Hoaki for sampling of sludge of the reactor.

\section{References}

Akasaka, H., Izawa, T., Ueki, K. \& Ueki, A. (2003a). Phylogeny of numerically abundant culturable anaerobic bacteria associated with degradation of rice plant residue in Japanese paddy field soil. FEMS Microbiol Ecol 43, 149-161.

Akasaka, H., Ueki, A., Hanada, S., Kamagata, Y. \& Ueki, K. (2003b). Propionicimonas paludicola gen. nov., sp. nov., a novel facultatively anaerobic, Gram-positive, propionate-producing bacterium isolated from plant residue in irrigated rice-field soil. Int J Syst Evol Microbiol 53, 1991-1998.

Altschul, S. F., Madden, T. L., Schäffer, A. A., Zhang, J., Zhang, Z., Miller, W. \& Lipman, D. J. (1997). Gapped BLAST and PSI-BLAST: a new generation of protein database search programs. Nucleic Acids Res 25, 3389-3402.

Bakir, M. A., Kitahara, M., Sakamoto, M., Matsumoto, M. \& Benno, Y. (2006). Bacteroides dorei sp. nov., isolated from human faeces. Int J Syst Evol Microbiol 56, 1639-1643.

Chassard, C., Delmas, E., Lawson, P. A. \& Bernalier-Donadille, A. (2008). Bacteroides xylanisolvens sp. nov., a xylan-degrading bacterium isolated from human faeces. Int J Syst Evol Microbiol 58, 1008 1013.

Chouari, R., Le Paslier, D., Daegelen, P., Ginestet, P., Weissenbach, J. \& Sghir, A. (2005). Novel predominant archaeal and bacterial groups revealed by molecular analysis of an anaerobic sludge digester. Environ Microbiol 7, 1104-1115.

Collins, T., Gerday, C. \& Feller, G. (2005). Xylanases, xylanase families and extremophilic xylanases. FEMS Microbiol Rev 29, 3-23.

Felsenstein, J. (2006). PHYLIP (phylogeny inference package), version 3.66. Department of Genome Sciences, University of Washington, Seattle, USA.

Fenner, L., Roux, V., Mallet, M. N. \& Raoult, D. (2005). Bacteroides massiliensis sp. nov., isolated from blood culture of a newborn. Int $J$ Syst Evol Microbiol 55, 1335-1337.

Garrity, G. M. \& Holt, J. G. (2001). The road map to the Manual. In Bergey's Manual of Systematic Bacteriology, 2nd edn, vol. 1, pp. 119166. Edited by D. R. Boone, R. W. Castenholz \& G. M. Garrity. New York: Springer.

Godon, J.-J., Zumstein, E., Dabert, P., Habouzit, F. \& Moletta, R. (1997). Molecular microbial diversity of an anaerobic digestor as determined by small-subunit rDNA sequence analysis. Appl Environ Microbiol 63, 2802-2813.

Hespell, R. B. \& Whitehead, T. R. (1990). Physiology and genetics of xylan degradation by gastrointestinal tract bacteria. J Dairy Sci 73, 3013-3022.

Holdeman, L. V., Cato, E. P. \& Moore, W. E. C. (1977). Anaerobe Laboratory Manual, 4th edn. Blacksburg, VA: Virginia Polytechnic Institute and State University.

Holdeman, L. V., Kelly, R. W. \& Moore, W. E. C. (1984). Genus I. Bacteroides Castellani and Chalmers 1919, 959. In Bergey's Manual of Systematic Bacteriology, vol. 1, pp. 604-631. Edited by N. R. Krieg \& J. G. Holt. Baltimore: Williams \& Wilkins.

Hopkins, M. J., Englyst, H. N., Macfarlane, S., Furrie, E., Macfarlane, G. T. \& McBain, A. J. (2003). Degradation of cross-linked and noncross-linked arabinoxylans by the intestinal microbiota in children. Appl Environ Microbiol 69, 6354-6360.

Hungate, R. E. (1966). The Rumen and its Microbes. New York: Academic Press.

Komagata, K. \& Suzuki, K. (1987). Lipid and cell-wall analysis in bacterial systematics. Methods Microbiol 19, 161-207.

Levén, L., Eriksson, A. R. B. \& Schnürer, A. (2007). Effect of process temperature on bacterial and archaeal communities in two methanogenic bioreactors treating organic household waste. FEMS Microbiol Ecol 59, 683-693. 
Miller, L. T. (1982). Single derivatization method for routine analysis of bacterial whole-cell fatty acid methyl esters, including hydroxyl acids. J Clin Microbiol 16, 584-586.

Miyagawa, E., Azuma, R. \& Suto, E. (1979). Cellular fatty acid composition in Gram-negative obligately anaerobic rods. J Gen Appl Microbiol 25, 41-51.

Moore, L. V. H., Bourne, D. M. \& Moore, W. E. C. (1994). Comparative distribution and taxonomic value of cellular fatty acids in thirty-three genera of anaerobic gram-negative bacilli. Int J Syst Bacteriol 44, 338347.

Nishiyama, T., Ueki, A., Kaku, N. \& Ueki, K. (2009a). Clostridium sufflavum sp. nov., isolated from a methanogenic reactor treating cattle waste. Int J Syst Evol Microbiol 59, 981-986.

Nishiyama, T., Ueki, A., Kaku, N., Watanabe, K. \& Ueki, K. (2009b). Bacteroides graminisolvens sp. nov., a xylanolytic anaerobe isolated from a methanogenic reactor treating cattle waste. Int J Syst Evol Microbiol 59, 1901-1907.

Paster, B. J., Dewhirst, F. E., Olsen, I. \& Fraser, G. J. (1994). Phylogeny of Bacteroides, Prevotella, and Porphyromonas spp. and related species. J Bacteriol 176, 725-732.

Saitou, N. \& Nei, M. (1987). The neighbor-joining method: a new method for reconstructing phylogenetic trees. Mol Biol Evol 4, 406425.

Shah, H. N. \& Collins, D. M. (1980). Fatty acid and isoprenoid quinone composition in the classification of Bacteroides melaninogenicus and related taxa. J Appl Bacteriol 48, 75-87.

Thompson, J. D., Higgins, D. G. \& Gibson, T. J. (1994). CLUSTAL W: improving the sensitivity of progressive multiple sequence alignment through sequence weighting, position-specific gap penalties and weight matrix choice. Nucleic Acids Res 22, 4673-4680.

Ueki, A., Matsuda, K. \& Ohtsuki, C. (1986). Sulfate reduction in the anaerobic digestion of animal waste. J Gen Appl Microbiol 32, 111123.

Ueki, A., Akasaka, H., Suzuki, D. \& Ueki, K. (2006a). Paludibacter propionicigenes gen. nov., sp. nov., a novel strictly anaerobic, Gramnegative, propionate-producing bacterium isolated from plant residue in irrigated rice-field soil in Japan. Int J Syst Evol Microbiol 56, 39-44.

Ueki, A., Akasaka, H., Suzuki, D., Hattori, S. \& Ueki, K. (2006b). Xylanibacter oryzae gen. nov., sp. nov., a novel strictly anaerobic, Gram-negative xylanolytic bacterium isolated from rice-plant residue in flooded rice-field soil in Japan. Int J Syst Evol Microbiol 56, 22152221.

Ueki, A., Akasaka, H., Suzuki, D., Satoh, A. \& Ueki, K. (2007). Prevotella paludivivens sp. nov., a novel strictly anaerobic, Gramnegative xylanolytic bacterium isolated from rice-plant residue in flooded rice-field soil in Japan. Int J Syst Evol Microbiol 57, 18031809.

Ueki, A., Abe, K., Kaku, N., Watanabe, K. \& Ueki, K. (2008). Bacteroides propionicifaciens sp. nov., isolated from rice-straw residue in a methanogenic reactor treating waste from cattle farms. Int J Syst Evol Microbiol 58, 346-352.

Whitehead, T. R., Cotta, M. A., Collins, M. D., Falsen, E. \& Lawson, P. A. (2005). Bacteroides coprosuis sp. nov., isolated from swinemanure storage pits. Int J Syst Evol Microbiol 55, 2515-2518.

Wilkins, T. D., Wagner, D. L., Veltri, B. J., Jr \& Gregory, E. M. (1978). Factors affecting production of catalase by Bacteroides. J Clin Microbiol 8, 553-557. 